\title{
Host migration and environmental temperature influence avian haemosporidians prevalence: a molecular survey in a Brazilian Atlantic Rainforest
}

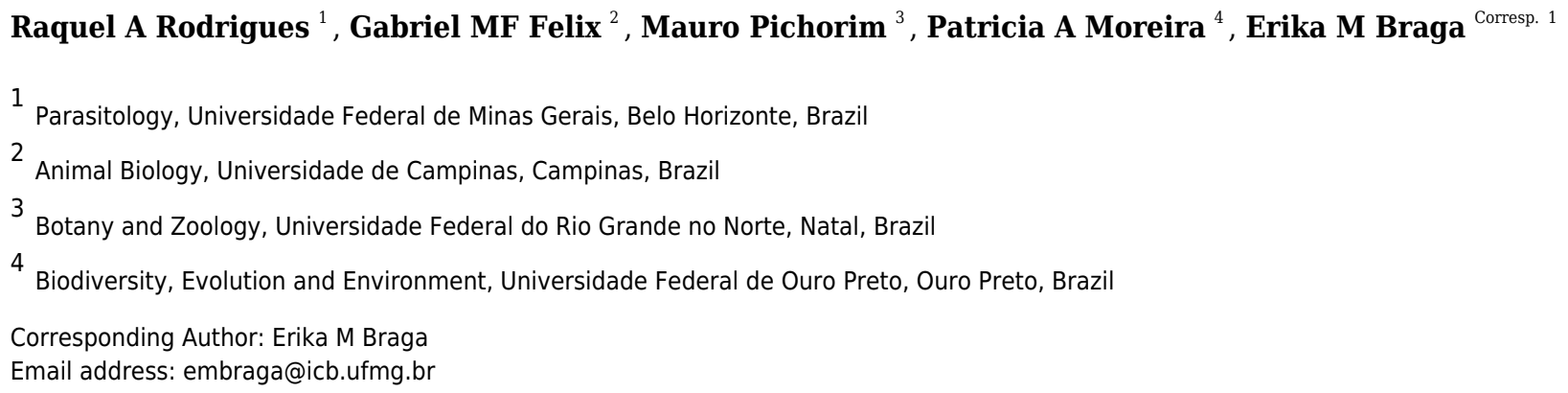

Avian haemosporidians are parasites with great capacity to spread to new environments and new hosts, being considered a good model to host-parasite interactions studies. Here, we examine avian haemosporidian parasites in a protected area covered by Restinga vegetation in northeastern Brazil, to test the hypothesis that haemosporidian prevalence is related to individual-level traits (age and breeding season), species-specific traits (diet, foraging strata, period of activity, species body weight, migratory status, and nest shape), and climate factors (temperature and rainfall). We screened DNA from 1,466 birds of 70 species captured monthly from April 2013 to March 2015. We detected an overall prevalence (Plasmodium/Haemoproteus infection) of 22\% (44 host species) and parasite's lineages were identified by mitochondrial cyt $b$ gene. Our results showed that migration can be an important factor predicting the prevalence of Haemoproteus (Parahaemoproteus), but not Plasmodium, in hosts. Besides, the temperature, but not rainfall, seems to predict the prevalence of Plasmodium in this bird community. Neither individual-level traits analyzed nor the other species-specific traits tested were related to the probability of a bird becoming infected by haemosporidians. Our results point the importance of conducting local studies in particular environments to understand the degree of generality of factors impacting parasite prevalence in bird communities. Despite our attempts to find patterns of infection in this bird community, we should be aware that an avian haemosporidian community organization is highly complex and this complexity can be attributed to an intricate net of factors, some of which were not observed in this study and should be evaluated in future studies. We evidence the importance of looking to host-parasite relationships in a more close scale, to assure that some effects may not be obfuscated by differences in host life-history. 
Host migration and environmental temperature influence avian haemosporidian prevalence: a molecular survey in a Brazilian Atlantic Rainforest

6 Raquel A. Rodrigues ${ }^{1}$, Gabriel M. F. Felix², Mauro Pichorim³, Patrícia A. Moreira ${ }^{4}$, Érika M.

7 Braga $^{1}$

9 'Parasitology, Universidade Federal de Minas Gerais, Belo Horizonte, Brazil

${ }^{2}$ Animal Biology, Universidade de Campinas, Campinas, Brazil.

${ }^{3}$ Botany and Zoology, Universidade Federal do Rio Grande no Norte, Natal, Brazil.

${ }^{4}$ Biodiversity, Evolution and Environment, Universidade Federal de Ouro Preto, Ouro Preto,

Brazil.

14 Corresponding Author:

15 Érika M. Braga ${ }^{1}$

16 Av. Presidente Antônio Carlos 6627, Pampulha, Belo Horizonte, MG 31270-901, Brazil.

17 Email address: embraga@icb.ufmg.br 


\section{Abstract}

21

22

Avian haemosporidians are parasites with a great capacity to spread to new environments and new hosts and, are considered a good model to study host-parasite interactions. Here, we examine avian haemosporidian parasites in a protected area covered by Restinga vegetation in northeastern Brazil, to test the hypothesis that haemosporidian prevalence is related to individual-level traits (age and breeding season), species-specific traits (diet, foraging strata, period of activity, species body weight, migratory status, and nest shape), and climate factors (temperature and rainfall). We screened DNA from 1,466 birds of 70 species captured monthly from April 2013 to March 2015. We detected an overall prevalence (Plasmodium/Haemoproteus infection) of $22 \%$ (44 host species) and parasite lineages were identified by mitochondrial cyt $b$ gene. Our results showed that migration can be an important factor predicting the prevalence of Haemoproteus (Parahaemoproteus), but not Plasmodium. Besides, the temperature, but not rainfall, seems to predict the prevalence of Plasmodium in this bird community. Neither individual-level traits analyzed nor the other species-specific traits tested were related to the probability of a bird becoming infected by haemosporidians. Our results point to the importance of conducting local studies in particular environments to understand the degree of generality of factors impacting parasite prevalence in bird communities. Despite our attempts to find patterns of infection in this bird community, we should be aware that an avian haemosporidian community organization is highly complex and this complexity can be attributed to an intricate net of factors, some of which were not observed in this study and should be evaluated in future surveys. We evidence the importance of looking to host-parasite relationships at a closer scale, to assure that some effects may not be obfuscated by differences in host life history. 


\section{Introduction}

45

46

47

48

49

50

51

52

53

54

55

56

57

58

59

60

61

62

63

64

65

66

67 efforts worldwide.

The avian haemosporidians of the genera Plasmodium and Haemoproteus are vectorborne parasites that infect a wide range of host species (Hellgren, Pérez-Triz \& Bensch, 2009; Ricklefs et al., 2014) and have frequently switched to new host species and new environments throughout their evolutionary history (Ricklefs, Fallon \& Bermingham, 2004;

ValkiūnasValkiūnas, 2005; Ricklefs et al., 2014; Ellis et al., 2019). These intracellular parasites reproduce sexually in different dipteran vectors: mosquitoes (Culicidae) are vectors of Plasmodium, and biting midges (Ceratopogonidae) and hippoboscid flies (Hippoboscidae) are vectors of Haemoproteus (Parahaemoproteus) and Haemoproteus (Haemoproteus), respectively (Valkiūnas, 2005; Santiago-Alarcon, Palinauskas \& Schaefer, 2012). Concerning their vertebrate hosts, Plasmodium and Haemoproteus (Parahaemoproteus) infect birds of various orders, while Haemoproteus (Haemoproteus) is more specific and infects birds of the order Columbiformes and some sea birds (Work \& Rameyer, 1996; Valkiūnas, 2005; Padilla et al., 2006; Levin \& Parker, 2012; Levin et al., 2012).

Haemosporidians are closely connected to their hosts in interaction with outcomes ranging from sublethal effects on the host fitness (Ortego et al., 2008; Knowles, Palinauskas \& Sheldon, 2010) to the decline and extinction of populations (van Riper III et al., 1986; Atkinson et al., 1995, 2000). These parasites can exert selective pressure on host populations through effects on reproductive success, lifetime, and survival (Hamilton \& Zuk, 1982; Scott, 1988; Spencer et al., 2005; Asghar et al., 2015; Ricklefs et al., 2016). Therefore, identifying the geographical distribution, host preferences, and infection prevalence of these parasites may help the development of appropriate management strategies to promote biodiversity conservation 

species and can be affected by several factors. Prevalence may increase with age of host, since

70

71

72

73

74

75

76

77

older individuals tend to have higher infection risk as a result of accumulated exposure to

parasites or potentially immunosenescence (Atkinson et al., 1995; Ricklefs et al., 2005; Wood et al., 2007; Eastwood et al., 2019). However, this relationship is not consistent among studies and is not always observed, which may be indicative that it depends on the parasite and host species studied (Wood et al., 2007; Antonini et al., 2019). Shape and height of birds nest may also influence haemosporidian prevalence, nest height must be associated with the spatial feeding preferences of vectors when seeking hosts, while its shape must determine the birds' exposure to vectors (Cerný, Votýpka \& Svobodová, 2011; Fecchio et al., 2011; González et al., 2014; Lutz et al., 2015; Matthews et al., 2015).

A migration strategy is another factor that may also influence haemosporidian prevalence in birds, since migratory species are exposed to different vectors and parasites as a consequence of their habitat change during their annual cycle (Waldenström et al., 2002; Hellgren et al., 2013; Ricklefs et al., 2017; Slowinski et al., 2018; Pulgarín-R et al., 2019; Soares, Latta \& Ricklefs, 2019). This relationship does not occur evenly between parasites and host species, as can be seen in studies that have observed that migratory birds can be infected by parasites from their wintering grounds (Waldenström et al., 2002) or have little or no haemosporidian lineage shared with resident birds (Ricklefs et al., 2017; Pulgarín-R et al., 2019). Likewise, the prevalence may be higher in migratory bird breeding (Hellgren et al., 2013) or wintering areas (Pulgarín-R et al., 2019).

Environmental factors can also be related to prevalence in a bird community. Seasonality, which involves temperature and rainfall, may influence vector infection dynamics and hence the 
91 haemosporidian transmission (Medeiros et al., 2016; Ferreira Junior et al., 2017; Hernández-

92 Lara, González-García \& Santiago-Alarcon, 2017a), and was even considered an important

93 driver of host specialization (Fecchio et al., 2019). However, seasonality, in the same way as the

94 host life-history traits, is not always linked to haemosporidian prevalence, not even in the tropics

95 (Ishtiaq, Bowden \& Jhala, 2017). Moreover, as seasonality is also associated with the breeding

96 period of birds, a relationship could be observed between these two variables influencing the

97 haemosporidian prevalence, since during bird's breeding season may be an increase in adult

98 susceptibility to infections, due to changes in its behavior and immunity (Drobney, Train \&

99 Fredrickson, 1983; Richner, Christe \& Oppliger, 1995; Ardia, 2005). Besides that, juveniles born

100 throughout this time may also be more susceptible to infections (Cosgrove et al., 2008; Møller,

101 2010; Santiago-Alarcon et al., 2011; Ferreira Junior et al., 2017; Rodrigues et al., 2020).

102 Therefore, many factors interact to determine the parasite prevalence in birds, revealing distinct

103 results in studies testing the same relationships in different communities. This makes the

104 knowledge of these interactions in different ecosystems valuable, to better understand the various

105 factors that interact and influence the dynamics of parasite-host infection in natural

106 environments.

107 Here, we tested whether the probability of an individual being infected with

108 haemosporidian parasites is related to (1) its individual-level traits (i.e., age and breeding

109 condition), which may influence the host immune defense mechanisms and individual exposure

110 to vectors; (2) its species-specific traits (i.e., diet, foraging strata, period of activity, species body

111 weight, migratory status, and nest shape), which may be linked to differential vector exposure;

112 and (3) climate factors (i.e., temperature and rainfall), which might influence in vector

113 abundance and richness. These hypotheses were tested in an area of Brazilian Restinga, a poorly 
114 sampled phytophiosionomy for hemoparasites, and therefore with a high potential to house new

115 haemosporidian lineages.

116

\section{Materials \& Methods}

118

119 Study site

120

The study was carried out in Barreira do Inferno Rocket Launch Center of the Brazilian

Air Force (acronym in Portuguese, Centro de Lançamento Barreira do Inferno - CLBI; 555’S

122

$35^{\circ} 9^{\prime} \mathrm{W}$ ), a protected area of $\sim 1,800$ ha located in Parnamirim, State of Rio Grande do Norte,

northeastern Brazil (Figure 1). The area is in a tropical coastal vegetation region, named

124

Restinga, which is a type of vegetation associated with the Atlantic Rainforest Domain (for more

details about the study site, see Rodrigues et al (2020)). Following the local climatic data (Fig.

S1), we determined as rainy season the period that goes from March to August and, as dry season

the period from September to February.

\section{Bird sampling}

We monitored monthly the haemosporidian infection in a bird community within a 30

ha plot $(550 \mathrm{~m} \times 550 \mathrm{~m})$ from April 2013 to March 2015. The birds were captured following the protocol described in Rodrigues et al (2020). All captured birds were identified and banded with individual aluminum bands provided by CEMAVE/ICMBio (permission 3239). Recaptured birds labial commissure, and cranial ossification; and the presence of brood patch, by visual 
137 sterile needle $(13 \times 4.5 \mathrm{~mm})$ and stored the blood in filter paper kept at $4^{\circ} \mathrm{C}$ until DNA 138 extraction.

139 Our use of mist-nets and banding was approved by the Brazilian biodiversity monitoring 140 agency (Institute Chico Mendes for Biodiversity Conservation-ICMBio, Brazilian National 141 Center for Bird Conservation - CEMAVE, permit 3239). We followed standard ethical protocols

142 for wildlife animals. Time handling the birds was kept to the minimum, and all birds were 143 released after banding, data, and sample collection. This study was approved by the Ethics

144 Committee in Animal Experimentation (CETEA), Universidade Federal de Minas Gerais, Brazil 145 (Protocol \#254/2011).

146

147 Parasite detection

148

The parasite detection followed the protocols described in Rodrigues et al (2020).

150 Lineages without previous records in the database were considered new lineages and deposited

151 in GenBank under accession numbers MH260577, MK291501-291507. New occurrences of

152 sequences previously described were also deposited in GenBank under accession numbers 153 MK264392-264411.

Modeling the factors predicting avian malaria prevalence

To test which factors influence the haemosporidian prevalence in the bird community,

158 we modeled the individual probability of infection separately for each parasite genus

159 (Plasmodium and Haemoproteus), as a function of individual and species-level traits of hosts, as 
160 well as the climatic conditions. We chose to model the individual probability of infection rather

161 than the prevalence in host populations (see Fecchio et al., 2013) since we have predictor

162 variables at the individual level, which included age of host (adult or young) and breeding

163 condition (breeding or non-breeding). The breeding condition was determined by the presence of

164 a brood patch at the time of the capture. Species-specific traits included average body mass $(\mathrm{g})$,

165 migratory status (migratory or resident), nest shape (open-cup vs closed), diet (frugivore,

166 nectarivore, granivore, insectivorous, omnivore, or combinations of two or three diets), foraging

167 stratum (ground, understory, midheight, canopy, and combinations of two or three foraging

168 strata), and period of activity (day or night). We obtained the species-specific traits data from

169 Handbook of the Birds of the World Alive (del Hoyo, Elliott \& Christie, 2011) and, from

170 Wilman et al. (2014). The classification of the diet was made considering the food item or the

171 combination of food items that covered at least $80 \%$ of the total diet, based on the data from

172 Wilman et al. (2014), using at most three main food items per species of bird. We considered as

173 migratory the species of birds with some type of seasonal displacement in the area, following the

174 classification used by Somenzari et al. (2018). Finally, we used mean monthly temperature and

175 total monthly precipitation for the climatic variables (through the 24 months study), which were

176 centered and scaled before analysis. We obtained the climate data from a Brazilian

177 Meteorological Database for Education and Research (INMET, 2017). Because in some cases we

178 were unable to obtain all the individual-level traits in the field, we removed from the dataset

179 individuals with missing information to run the analysis.

180 We accounted for different types of pseudoreplication (Hurlbert, 1984) in our dataset.

181 Phylogenetically related bird species, for instance, would have similar infection probabilities

182 (Ricklefs \& Fallon, 2002; Waldenström et al., 2002), as well as individuals captured at the same 
183 occasion (same month and same seasonality; Kim and Tsuda 2010; Ferreira Junior et al. 2017).

184 Therefore, to control for such potential dependences, we used the R package lme4 (Bates et al., 185 2015; R Core Team, 2016; Harrison et al., 2018) to fit Generalized Linear Mixed Models

186 (GLMM; Bolker et al., 2009). The infection status was recorded as a binary response variable (0:

187 uninfected; 1: infected) and modeled as a Bernoulli trial with a binomial distribution of errors

188 and the logit link function. The hosts individual- and species-level traits, and the climatic 189 conditions entered as fixed factors, without any interactions; and the temporal (season and 190 month) and phylogenetic (order, family, gender, species) factors entered as random factors 191 nested within each dimension (temporal: month nested in season; phylogenetic: species nested in 192 the genus, and genus nested in the family) and crossed among dimensions. Here we used data 193 referring to the taxonomic classification of birds, considering that this is similar to the currently 194 known phylogenetic classification. The random effects were modeled affecting only the 195 intercept, but not the slope of the model.

196 The final model was obtained by Backward selection of the fixed factors only - the 197 random structure was maintained complete in all models (Barr et al., 2013). Starting from the full 198 model, we used the likelihood ratio test to remove the fixed factors that do not contribute 199 significantly to the model fit (Crawley, 2013). The likelihood ratio test compares the data 200 likelihood under the full model against the data likelihood under a model with fewer factors and 201 was performed using an analysis of variance (ANOVA) performed by the anova function. In 202 each step, we removed the fixed factors that explained the small part of the deviance. We used 203 the r.squaredGLMM function implemented in the R package MuMIn (Barton, 2018) to compute 204 both the marginal and conditional $\mathrm{R}^{2}$ for the final model; and the icc function implemented in the 205 R package sjstats to compute the adjusted intraclass-correlation of the random factors. The 
206 marginal- $\mathrm{R}^{2}$ gives the percentage of variance explained by the fixed factors, while the 207 conditional- $\mathrm{R}^{2}$ gives the total percentage of variance explained by the full model, including the 208 fixed and the random factors (Nakagawa \& Schielzeth, 2013). Finally, the adjusted intraclass 209 correlation gives the percentage of the residual variance explained by each random factor 210 (Nakagawa, Johnson \& Schielzeth, 2017). The overdispersion test was not necessary, because an 211 overdispersion test does not make sense with a binary response variable (Crawley, 2013). All 212 these analyses were made separately for each parasite genus (i.e., Plasmodium and 213 Haemoproteus), but we included in the dataset only host species with at least one individual 214 infected by the parasite genus that was being analyzed on each occasion.

215

\section{Results}

217

218

219

220

221

222

223

224

225

226

227

228

229

\section{Overall malaria prevalence}

We captured 1,466 individual birds of 25 families and 70 bird species, of which 322 (22\%, 44 species) were infected by Plasmodium/Haemoproteus. All samples that screened positive were subjected to the cytochrome $b$ PCR, which successfully amplified infections from 145 individuals. We obtained high-quality sequences from 117 samples. This is a wellestablished methodology for detecting haemosporidians that has been successfully applied in many other studies (e.g. Lacorte et al., 2013; Fecchio et al., 2017a; Ferreira Junior et al., 2017; Ricklefs et al., 2017; Ferreira et al., 2020; Lopes et al., 2020; Rodrigues et al., 2020; Soares, Young \& Ricklefs, 2020), allowing us to observe the parasite prevalence and richness in a host community and compare the identified lineages with other haemosporidian studies around the world. Unfortunately, we were not able to collect and analyze blood smears from the captured birds, which would greatly enrich our findings and allow us to assess the discrepancy between 
230 the number of positive samples and the number of successfully sequenced lineages. We detected

231 Plasmodium in 35 individuals of 18 species (Table 1) and Haemoproteus infections were

232 detected in 67 individuals of 15 species (Table 2). Among more highly-captured species $(\mathrm{n} \geq 7)$,

233 the highest prevalence of infection were detected in Cyclarhis gujanensis ( $\mathrm{n}=9 / 14,64.3 \%)$,

234 Tachyphonus rufus $(\mathrm{n}=69 / 108,64 \%)$, and Columbina passerina $(\mathrm{n}=11 / 21,52.4 \%)$. The majority

235 of bird species caught is resident in the region, but we have captured 15 migratory species of

236 which nine were infected (Elaenia spp. [3 species; n=69/431], Myiarchus tyrannulus [1/4],

237 Turdus amaurochalinus [23/164], Schistochlamys ruficapillus [4/13], Turdus flavipes [3/13],

238 Cyanerpes cyaneus [1/1] and Vireo chivi [5/10]; Table S1).

239

240

Haemosporidian diversity

241

242

We recovered 27 cyt $b$ lineages from 117 individuals, of which 18 were Plasmodium

243 lineages, detected in 35 birds (18 species), and 9 were Haemoproteus lineages, detected in 67

244 birds. Fifteen of the 117 high-quality sequences exhibited multiple infections, based on double

245 peaks in the chromatograms, and were removed from the dataset. Among the Haemoproteus

246 lineages, 3 were Haemoproteus (Haemoproteus) lineages detected in 9 birds (2 species), and 6

247 were Haemoproteus (Parahaemoproteus) lineages detected in 58 birds (13 species), as shown in

248 Table 2. A total of eight lineages were detected here for the first time (five Plasmodium and three

249 H. (Parahaemoproteus). Of the 27 lineages, 14 (52\%) were detected only once. Of the 13

250 lineages detected at least twice, eight (30\%) were found in more than one host species (Table 1

251 and Table 2). Most of the lineages detected in only one host species were found in only one

Peer) reviewing PDF | (2020:09:53198:2:0:NEW 5 May 2021) 
252 individual (14 lineages), and the remaining lineages were found in two (2 lineages), three (1

253 lineage), or four (2 lineages) individuals.

254 Despite the higher richness of Plasmodium lineages detected in birds, there was a higher 255 number of birds infected by Haemoproteus ( 35 and 67 birds, respectively), mainly by $H$.

256 (Parahaemoproteus). The most prevalent Plasmodium lineage was BAFLA04, detected in 7

257 birds, being four captured at the rainy season and three at the dry season. Among the

258 Parahaemoproteus lineages, we highlight the lineage TARUF02, which was detected here for 259 the first time in 44 birds (21 at the rainy season and 23 at the dry season) and have an apparent 260 preference in infecting birds of the species Tachyphonus rufus. Of the total 44 birds infected by

261 this lineage, 37 were $T$. rufus species, and the other seven occurrences of this lineage were 262 detected in seven different bird species (Table 1 and Table 2). Besides, we recorded only two 263 infections by other lineages in T. rufus species (PADOM11 and BAFLA04).

264

265

Factors predicting haemosporidian prevalence

266

267 Our final dataset for prevalence analysis, after excluding individuals with missing data, 268 included 1,187 individual birds. Although the subgenus Haemoproteus (Haemoproteus) and $H$.

269 (Parahaemoproteus) are classified within the same genus, they are very different concerning 270 their vertebrate hosts and vectors (Valkiūnas, 2005), which made us consider it important to treat 271 these two groups differently in our study. However, as the number of birds infected by $H$.

272 (Haemoproteus) was too low $(\mathrm{n}=9)$, we only included in these analyses birds infected by $H$. 273 (Parahaemoproteus). 
The GLMM analysis indicated that the temperature influences the probability of

275 infection by Plasmodium (Table S2), with the increase of one standard deviation on temperature

$276\left(0.99^{\circ} \mathrm{C}\right)$ resulting in an increase of 1.8 in the odds of infection by Plasmodium (the odds ratio,

277 Table 3). However, the temperature is not an important factor influencing the probability of

278 infection by Parahaemoproteus and neither Plasmodium nor Parahaemoproteus were influenced

279 by rainfall.

280

The probability of infection was not influenced by any of the individual host traits

281 tested, such as age and breeding condition for both parasite genus. Besides, when considering

282 species-specific traits, only the probability of infection by Parahaemoproteus was affected by

283 the species migratory status (Table S3), with the odds of be infected by Parahaemoproteus in

284 migratory birds being 0.03 of that in non-migratory birds. However, there was no influence on

285 the probability of infection by any haemosporidian when considering diet, foraging stratum,

286 period of activity, species body mass, and nest shape.

287

For Parahaemoproteus GLMM the $\mathrm{ICC}_{\text {adj }}$ was equal to zero for all random factors

288

289

290

291

292

293

294

295

296

(Table S4), and, consequently, marginal and conditional $\mathrm{R}^{2}$ were identical $\left(\mathrm{R}_{\mathrm{m}}^{2}=\mathrm{R}_{\mathrm{c}}^{2}=0.43\right.$,

Table 3). This means that the random factors do not explain anything about the dispersion of

model residuals. In this case, the GLMM collapse to a simple GLM. For Plasmodium GLMM, otherwise, the $\mathrm{ICC}_{\mathrm{adj}}$ was also equal to zero for almost all random factors, except for random factor 'species' which was equal to 0.17 (Table S4), indicating that $17 \%$ of the residual variance is correlated within species. Thus, marginal and conditional $\mathrm{R}^{2}$ were not identical $\left(\mathrm{R}_{\mathrm{m}}^{2}=0.08\right.$, and $\mathrm{R}_{\mathrm{c}}^{2}=0.24$, Table 3 ) and, therefore, the species of the birds had a small influence on the probability of Plasmodium infection. This indicates that, apart from the other factors, birds of different species will have different probabilities of becoming infected by Plasmodium. 


\section{Discussion}

300

301

What does influence avian haemosporidian prevalence? Here, we found that migratory

302

birds were less likely to be infected with Haemoproteus (Parahaemoproteus) when compared to

resident birds and that the probability of infection by Plasmodium was positively influenced by

304

temperature. By observing avian haemosporidians in a diverse region, and exploring how

305

ecological variables are related to parasite infection probability in wild birds, we can compare

306

these interactions we have found here with patterns of interactions already observed in avian

communities in different contexts, to add knowledge that allows us to better understand

infectious diseases in wild birds.

Migratory behavior of birds from CLBI had a significant and inverse association with the probability of infection by Haemoproteus (Parahaemoproteus), but there was no effect of migration on the probability of infection by Plasmodium. The current knowledge of the host specificity of the parasite lineages predicts that Haemoproteus parasites tend to be more hostspecific than Plasmodium parasites (Ishtiaq et al., 2007, 2010; Dimitrov, Zehtindjiev \& Bensch, 2010). Therefore, it is possible that migratory birds are not suitable hosts for Parahaemoproteus lineages with which they geographically overlap during their annual cycle. This agrees with the study presented by Hellgren et al. (2007) showing that Haemoproteus and Leucocytozoon had a

317 significant affiliation to a single resident bird fauna, while Plasmodium lineages showed a higher 318 degree of infecting both resident and migratory bird species. If that is true in the studied bird 319 community, migrants may be less likely to become infected by Haemoproteus in CLBI when 320 compared to resident birds, due to the greater specificity this parasite presents concerning its 
321 local hosts. Because Plasmodium lineages are usually more generalist, they can probably infect

322 migrants as well as resident birds, which would explain why we did not find the same influence 323 of migratory behavior on the probability of infection by these parasites. If, on the one hand, the

324 migration has the potential to increase the exposure of birds to parasites by concentrating 325 individuals at breeding, overwintering or, migratory stopover sites (Waldenström et al., 2002),

326 on the other hand, migration could make possible the escape of birds from habitats where 327 parasite transmission stages have accumulated, or selective removal of infected hosts during 328 movements (Hall, Altizer \& Bartel, 2014).

329 Alternatively, our results might be related to the hypothesis that the selection experienced 330 by migratory birds in their breeding and wintering areas resulted in greater investment in 331 immune defense (Møller \& Erritzøe, 1998). If a bird individual is negative for haemosporidian 332 infections, it might be because either the host individual is not infected, the parasite is dormant in 333 tissues and not found in the bloodstream (Valkiūnas, 2005), or that it occurs in such low 334 intensities in the avian blood that it is not detected by PCR screening. This former situation could 335 be a cue that the bird was able to fight the infection, reducing its parasitemia. In that case, 336 migrants having greater investment in immune defense could also have low parasitemia when 337 infected.

338 Despite the absence of data about mosquitoes in CLBI to allow us to correctly evaluate 339 the vector-parasite-host relationship, the positive association observed between temperature and 340 Plasmodium prevalence may be related to the effects of temperature on the vectors of this

341 parasite. For avian haemosporidians, the temperature is commonly described as an important

342 abiotic factor influencing the parasite development and vector breeding opportunities (Beier, 343 1998; Santiago-Alarcon, Palinauskas \& Schaefer, 2012; Medeiros et al., 2016; Mordecai et al., 
344 2019). It has been demonstrated that the development of different malaria parasites in vectors

345 can be influenced by the climate and is generally hampered by low increments in temperature

346 (LaPointe, Goff \& Atkinson, 2010; Zamora-Vilchis, Williams \& Johnson, 2012). Temperature

347 also determines the rate at which mosquitoes develop into adults, the frequency of their blood-

348 feeding, and the rate at which parasites are acquired (Patz et al., 2000). Garamszegi (2011) has

349 shown that a $1^{\circ} \mathrm{C}$ increase in global temperature led to a two- to three-fold increase in the 350 average prevalence of Plasmodium in birds. It is also demonstrated that studies made with

351 samples from years and localities where temperature anomalies were strongly expressed

352 generally detected higher Plasmodium prevalence than surveys based on samples that were less

353 affected by temperature anomalies (Garamszegi, 2011). Sehgal et al. (2011), in a study

354 conducted on Olive Sunbirds (Cyanomitra olivacea) in West and Central Africa, also showed an 355 association between higher temperatures and elevated Plasmodium prevalence, with data

356 indicating that the maximum temperature of the warmest month was the most important indicator

357 for elevated malaria prevalence. In contrast, Zamora-Vilchis et al. (2012), in a study conducted

358 in Australia, demonstrated that in areas with high temperatures the birds had a higher prevalence

359 of Haemoproteus, and relationships for Leucocytozoon and Plasmodium were also positive but

360 not statistically significant. Given that, in a warmer climate, the vector abundance may increase,

361 and the transmission of vector-borne diseases must be higher. On the other hand, in our study the

362 infection probability by Parahaemoproteus lineages was not influenced by temperature and, it is

363 possible that biting midges, which act as their vectors, do not have their reproduction and

364 development as closely related to climatic factors as Plasmodium vectors. Immature biting

365 midges require a certain amount of free water or moisture, being able to develop in a wide range

366 of habitats that meet that criterion like pools, streams, marshes, bogs, beaches, swamps, tree 
367 holes, irrigation pipe leaks, saturated soil, animal dung, and even rotting fruit and other

368 vegetation (Mellor, Boorman \& Baylis, 2000). With so many possible breeding sites,

369 Parahaemoproteus vectors are probably present in the community during the whole year and,

370 even if there is some reduction in their abundance due to changes in temperature and rainfall

371 (Mellor, Boorman \& Baylis, 2000), it may be less evident for biting midges than for mosquitoes.

$372 \quad$ Neither age nor breeding condition explained the probability of infection by

373 haemosporidians. Although many studies have evidenced that birds age and/or breeding

374 condition may influence haemosporidian prevalence (Wood et al., 2007; Ferreira Junior et al.,

375 2017; Hernández-Lara, González-García \& Santiago-Alarcon, 2017b; Eastwood et al., 2019),

376 others have failed to detect such an association (Ricklefs et al., 2005; Matthews et al., 2015).

377 There was also no association between prevalence and rainfall or, except for migratory behavior,

378 any tested species-specific traits (diet, foraging strata, period of activity, species body weight,

379 and nest shape). It is true that many studies have shown that different host-traits and abiotic

380 factors are important determinants in a host-parasite interaction (Ricklefs et al., 2005; Wood et

381 al., 2007; Medeiros et al., 2016; Ferreira Junior et al., 2017; Hernández-Lara, González-García \&

382 Santiago-Alarcon, 2017a; Ishtiaq, Bowden \& Jhala, 2017; Fecchio et al., 2017b; Eastwood et al.,

383 2019). However, there are many variations in these studies' results, and some of them fail to

384 detect these interactions. Based on the mixed results found in these studies, it is possible that the

385 relationship between species-specific traits as well as individual-level traits and the risk of

386 infection by haemosporidian parasites might be location-dependent. It is important to highlight

387 that several factors might be working together to determine such variations we see in all these

388 different studies, including the host species that, as we observed, had a small influence on the

389 infection probability by Plasmodium. That small influence of the species on Plasmodium 
390 prevalence could be related to factors that were not tested in our studies, like phylogeny or co-

391 infection with other hemoparasites. Studying haemosporidian infections only at the community

392 level reduces our ability to detect if some species are more susceptible to the most common

393 Plasmodium lineages in CLBI, for example. That is why species-specific studies are also

394 important and allow us to identify some relationships that may be overshadowed in a bird

395 community (Rodrigues et al., 2020).

396 The CLBI harbors a diverse community of avian haematozoan lineages distributed

397 among $63 \%$ (44/70) of the bird species sampled in this study and we estimated an overall

398 parasite prevalence of $\sim 22 \%$. Estimates for the prevalence of haemosporidian parasites in bird

399 communities from Brazil indicate a great variation both among different ecosystems and between

400 different sites in the same ecosystems. The estimated prevalence in Cerrado varied from $21 \%$ to

$40142 \%$ (Belo et al., 2011; Fecchio et al., 2013; Lacorte et al., 2013). In other Brazilian habitats it

402 has also been observed a great variation in prevalence estimates, e.g. 17.4\% (Fecchio et al.,

403 2017c) to 21.7\% (Svensson-Coelho et al., 2013) in Amazonian Region; 38.5\% (Lacorte et al.,

4042013 ) to $42 \%$ (Ferreira Junior et al., 2017) in Seasonally Dry Tropical Forest; and $12.4 \%$ to

$40539.6 \%$ in Atlantic Forest (Ribeiro et al., 2005; Sebaio et al., 2010; Lacorte et al., 2013). This

406 considerable variation in prevalence among studies is evidence that we still have many aspects of

407 this complex, spatially variable parasite-host system to understand. The avian haemosporidian

408 parasite-host community in northeast Brazil adds to our understanding of the distribution and

409 diversity of avian haemosporidian parasites and examines the ecological factors that influence

410 host susceptibility. However, we acknowledge that much remains to be investigated in the

411 parasite-host relationship in Restinga and suggest that future studies use information from blood 
412 smears and mixed infections to extend the ability to detect and identify haemosporidians in this

413 bird community.

414

415

416

\section{Conclusions}

418

419

In this first exploration of avian haemosporidian parasites in a largely unexplored region 420 of Brazil, we could demonstrate that this environment harbors a high diverse community of Plasmodium and Haemoproteus parasites. We established that migration can be an important factor predicting the prevalence of Haemoproteus, but not Plasmodium, in hosts. Thus, in CLBI, Haemoproteus lineages infect preferably resident birds and should be more difficult to disperse into new environments. The other individual- and species-level traits were not important in determining the probability of infection by Plasmodium or Haemoproteus in our study, which indicates a great variation of the influence of these factors on haemosporidian prevalence in different communities. The temperature, but not the rainfall, seems to predict the Plasmodium prevalence in this bird community. This result raises the possibility that ongoing climate change will impact the dynamics of Plasmodium transmission, a subject that should be explored in future studies. The higher number of birds infected by Haemoproteus lineages than by Plasmodium is an uncommon finding in Brazil and led us to suggest that northeast Brazil must have a different haemosporidian infection dynamics when compared to other studied regions of the country. Further investigations in northeast biomes and sampling of the haemosporidian vectors are needed to better understand the transmission dynamics and to elucidate the factors promoting higher levels of Haemoproteus infection in birds of this region. 
437

438

439

440 We thank the Centro de Lançamento Barreira do Inferno (CLBI, Brazilian Air Force), and to the

441

442

443

444 Eric Pereira for designing the map of our sampling area.

445

446

447

448

449

450

451

452

453

454

455

456

457

458

459

460

461

462

463

\section{Acknowledgements}

Brazilian National Center for Bird Conservation (CEMAVE/ICMBio) for support. We also thank

all LabOrnito - UFRN ornithologists and students for their valuable help in the field and

laboratory work, especially Lidiane M. Andrade and Priscilla S. A. Araújo. We are grateful to

\section{References}

Antonini Y, Lobato DNC, Ramos JA, Moreira P de A, Braga EM. 2019. Patterns of avian malaria in tropical and temperate environments: testing the "The enemy release hypothesis." Biota Neotropica 19:1-6.

Ardia DR. 2005. Individual quality mediates trade-offs between reproductive effort and immune function in tree swallows. Journal of Animal Ecology 74:517-524. DOI: 10.1111/j.13652656.2005.00950.x.

Asghar M, Hasselquist D, Hansson B, Zehtindjiev P, Westerdahl H, Bensch S. 2015. Hidden costs of infection: Chronic malaria accelerates telomere degradation and senescence in wild birds. Science 347:436-438. DOI: 10.1126/science.1261121.

Atkinson CT, Dusek RJ, Woods KL, Iko WM. 2000. Pathogenicity of avian malaria in experimentally-infected Hawaii Amakihi. Journal of Wildlife Diseases 36:197-204. DOI: $10.7589 / 0090-3558-36.2 .197$. 
464 Atkinson CT, Woods KL, Dusek RJ, Sileo LS, Iko WM. 1995. Wildlife disease and conservation 465 in Hawaii: Pathogenicity of avian malaria (Plasmodium relictum) in experimentally infected $466 \quad$ Iiwi (Vestiaria coccinea). Parasitology 111:S59-S69.

467 Barr DJ, Levy R, Scheepers C, Tily HJ. 2013. Random effects structure for confirmatory 468 hypothesis testing: Keep it maximal. Journal of Memory and Language 68:1-43. DOI: $469 \quad$ 10.1016/j.jml.2012.11.001.

470 Barton K. 2018. Package "MuMIn.” cran.r-project.org. DOI: Available at www.cran.r$471 \quad$ project.org/web/packages.

472 Bates D, Mächler M, Bolker BM, Walker SC. 2015. Fitting Linear Mixed-Effects Models Using 473 lme4. Journal of Statistical Software 67:1-48. DOI: 10.18637/jss.v067.i01.

474 Beier JC. 1998. Malaria Parasite Development in Mosquitoes. Annual Review of Entomology 475 43:519-543. DOI: 10.1146/annurev.ento.43.1.519.

476

477

478

479

480

481

482

483

484

485

486

Belo NO, Pinheiro RT, Nia E, Reis S, Ricklefs RE, Braga M. 2011. Prevalence and Lineage Diversity of Avian Haemosporidians from Three Distinct Cerrado Habitats in Brazil. PLoS ONE 6:1-8. DOI: 10.1371/journal.pone.0017654.

Bolker BM, Brooks ME, Clark CJ, Geange SW, Poulsen JR, Stevens MHH, White JSS. 2009. Generalized linear mixed models: a practical guide for ecology and evolution. Trends in Ecology and Evolution 24:127-135. DOI: 10.1016/j.tree.2008.10.008.

Cerný O, Votýpka J, Svobodová M. 2011. Spatial feeding preferences of ornithophilic mosquitoes, blackflies and biting midges. Medical and Veterinary Entomology 25:104-108. DOI: $10.1111 /$ j.1365-2915.2010.00875.x.

Cosgrove CL, Wood MJ, Day KP, Sheldon BC. 2008. Seasonal variation in Plasmodium prevalence in a population of blue tits Cyanistes caeruleus. Journal of Animal Ecology 
77:540-548. DOI: 10.1111/j.1365-2656.2008.01370.x.

488 Crawley MJ. 2013. The R book. London: John Wiley \& Sons Ltd.

489 Dimitrov D, Zehtindjiev P, Bensch S. 2010. Genetic diversity of avian blood parasites in SE

490 Europe: Cytochrome b lineages of the genera Plasmodium and Haemoproteus

491 (Haemosporida) from Bulgaria. Acta Parasitologica 55:201-209. DOI: 10.2478/s11686-

$492 \quad$ 010-0029-z.

493 Drobney RD, Train CT, Fredrickson LH. 1983. Dynamics of the platyhelminth fauna of wood

494 ducks in relation to food habits and reproductive state. The Journal of Parasitology 69:375-

495380.

496 Eastwood JR, Peacock L, Hall ML, Roast M, Murphy SA, Silva AG, Peters A. 2019. Persistent

497 low avian malaria in a tropical species despite high community prevalence. IJP: Parasites

$498 \quad$ and Wildlife 8:88-93. DOI: 10.1016/j.ijppaw.2019.01.001.

499 Ellis VA, Sari EHR, Rubenstein DR, Dickerson RC, Bensch S, Ricklefs RE. 2019. The global

500 biogeography of avian haemosporidian parasites is characterized by local diversification

501 and intercontinental dispersal. Parasitology 146:213-219. DOI:

$502 \quad 10.1017 / \mathrm{S} 0031182018001130$.

503 Fecchio A, Ellis VA, Bell JA, Andretti CB, D’horta FM, Silva AM, Tkach V V., Weckstein JD.

504 2017b. Avian malaria, ecological host traits and mosquito abundance in southeastern

505 Amazonia. Parasitology 144:1117-1132. DOI: 10.1017/S003118201700035X.

506 Fecchio A, Wells K, Bell JA, Tkach V V., Lutz HL, Weckstein JD, Clegg SM, Clark NJ. 2019.

507 Climate variation influences host specificity in avian malaria parasites. Ecology Letters

$508 \quad$ 22:547-557. DOI: 10.1111/ele.13215.

509 Fecchio A, Lima MR, Silveira P, Braga ÉM, Marini MÂ. 2011. High prevalence of blood 
parasites in social birds from a neotropical savanna in Brazil. Emu 111:132-138. DOI:

511

512 Fecchio A, Svensson-Coelho M, Bell J, Ellis VA, Medeiros MC, Trisos CH, Blake JG, Loiselle 513 BA, Tobias JA, Fanti R, Coffey ED, De Faria IP, Pinho JB, Felix G, Braga EM, Anciães M, 514 Tkach V, Bates J, Witt C, Weckstein JD, Ricklefs RE, Farias IP. 2017a. Host associations 515 516 and turnover of haemosporidian parasites in manakins (Aves: Pipridae). Parasitology 144:984-993. DOI: 10.1017/S0031182017000208.

Fecchio A, Pinheiro R, Felix G, Faria IP, Pinho JB, Lacorte GA, Braga EM, Farias IP, Aleixo A, Tkach V V, Collins MD, Bell JA, Weckstein JD. 2017c. Host community similarity and geography shape the diversity and distribution of haemosporidian parasites in Amazonian birds. Ecography 0:1-10. DOI: 10.1111/ecog.03058.

Fecchio A, Lima MR, Svensson-Coelho M, Marini MÂ, Ricklefs RE. 2013. Structure and organization of an avian haemosporidian assemblage in a Neotropical savanna in Brazil. Parasitology 140:181-192. DOI: 10.1017/S0031182012001412.

Ferreira Junior FC, Rodrigues RA, Ellis VA, Leite LO, Borges MAZ, Braga ÉM. 2017. Habitat modification and seasonality influence avian haemosporidian parasite distributions in southeastern Brazil. PLoS ONE 12:1-18.

Ferreira FC, Alves LGM, Jager GB, Franzini LD, Mesquita DO, Díaz-Delgado J, Catão-Dias JL, Braga ÉM. 2020. Molecular and pathological investigations of Plasmodium parasites infecting striped forest whiptail lizards (Kentropyx calcarata) in Brazil. Parasitology Research 119:2631-2640. DOI: 10.1007/s00436-020-06756-7.

Garamszegi LZ. 2011. Climate change increases the risk of malaria in birds. Global Change Biology 17:1751-1759. DOI: 10.1111/j.1365-2486.2010.02346.x. 
533 González AD, Matta NE, Ellis VA, Miller ET, Ricklefs RE, Gutiérrez HR. 2014. Mixed species

534 flock, nest height, and elevation partially explain avian haemoparasite prevalence in

535 Colombia. PLoS ONE 9. DOI: 10.1371/journal.pone.0100695.

536 Hall RJ, Altizer S, Bartel RA. 2014. Greater migratory propensity in hosts lowers pathogen

537 transmission and impacts. Journal of Animal Ecology 83:1068-1077. DOI: 10.1111/1365-

$538 \quad 2656.12204$.

539 Hamilton WD, Zuk M. 1982. Heritable true fitness and bright birds: A role for parasites? Science $540 \quad 218: 384-387$.

541 Harrison XA, Donaldson L, Correa-Cano ME, Evans J, Fisher DN, Goodwin CED, Robinson

542 BS, Hodgson DJ, Inger R. 2018. A brief introduction to mixed effects modelling and multi543 model inference in ecology. PeerJ 6:e4794. DOI: 10.7717/peerj.4794.

544 Hellgren O, Pérez-Triz J, Bensch S. 2009. A jack-of-all-trades and still a master of some:

545 prevalence and host range in avian malaria and related blood parasites. Ecology 90:2840546 2849. DOI: $10.1890 / 08-1059.1$.

547 Hellgren O, Wood MJ, Waldenström J, Hasselquist D, Ottosson U, Stervander M, Bensch S.

548 2013. Circannual variation in blood parasitism in a sub-Saharan migrant passerine bird, the 549 garden warbler. Journal of Evolutionary Biology 26:1047-1059. DOI: 10.1111/jeb.12129.

550 Hellgren O, Waldenström J, Peréz-Tris J, Szöll Ösi E, Hasselquist D, Krizanauskiene A,

551 Ottosson U, Bensch S. 2007. Detecting shifts of transmission areas in avian blood parasites 552 - A phylogenetic approach. Molecular Ecology 16:1281-1290. DOI: 10.1111/j.1365$553 \quad 294 X .2007 .03227 . x$.

554 Hernández-Lara C, González-García F, Santiago-Alarcon D. 2017a. Landscape and urban 555 planning spatial and seasonal variation of avian malaria infections in five different land use 

157:151-160. DOI: 10.1016/j.landurbplan.2016.05.025.

Hernández-Lara C, González-García F, Santiago-Alarcon D. 2017b. Spatial and seasonal variation of avian malaria infections in five different land use types within a Neotropical montane forest matrix. Landscape and Urban Planning 157:151-160. DOI:

561 10.1016/j.landurbplan.2016.05.025.

562

del Hoyo J, Elliott A, Christie DA. 2011. Handbook of the birds of the world alive. Barcelona: Lynx Edicions.

564

565

566

567

568

569

570

571

572

573

574

575

576

577

578

Hurlbert SH. 1984. Pseudoreplication and the Design of Ecological Field Experiments. Ecological Monographs 54:187-211.

INMET. 2017.Instituto Nacional de Meteorologia. Banco de Dados Meteorológicos para Ensino e Pesquisa - BDMEP. Brasília, DF, Brasil. Available at http://www.inmet.gov.br/portal/index.php? $r=b d m e p / b d m e p($ accessed December 11, 2017).

Ishtiaq F, Bowden CGR, Jhala Y V. 2017. Seasonal dynamics in mosquito abundance and temperature do not influence avian malaria prevalence in the Himalayan foothills. Ecology and Evolution 7:8040-8057. DOI: 10.1002/ece3.3319.

Ishtiaq F, Clegg SM, Phillimore AB, Black RA, Owens IPF, Sheldon BC. 2010. Biogeographical patterns of blood parasite lineage diversity in avian hosts from southern Melanesian islands. Journal of Biogeography 37:120-132. DOI: 10.1111/j.1365-2699.2009.02189.x.

Ishtiaq F, Gering E, Rappole JH, Rahmani AR, Jhala Y V, Dove CJ, Milensky C, Olson SL, Peirce MA, Fleischer RC. 2007. Prevalence and diversity of avian Hematozoan parasites in Asia: a regional survey. Journal of Wildlife Diseases 43:382-398.

Kim KS, Tsuda Y. 2010. Seasonal changes in the feeding pattern of Culex pipiens pallens govern 
579

580

581

582

583

584

585

586

587

588

589

590

591

592

593

594

595

596

597

598

599

600

601

the transmission dynamics of multiple lineages of avian malaria parasites in Japanese wild bird community. Molecular Ecology 19:5545-5554. DOI: 10.1111/j.1365294X.2010.04897.x.

Knowles SCL, Palinauskas V, Sheldon BC. 2010. Chronic malaria infections increase family inequalities and reduce parental fitness: Experimental evidence from a wild bird population. Journal of Evolutionary Biology 23:557-569. DOI: 10.1111/j.1420-9101.2009.01920.x.

Lacorte GA, Flix GMF, Pinheiro RRB, Chaves A V., Almeida-Neto G, Neves FS, Leite LO, Santos FR, Braga ÉM. 2013. Exploring the Diversity and Distribution of Neotropical Avian Malaria Parasites - A Molecular Survey from Southeast Brazil. PLoS ONE 8:1-9. DOI: 10.1371/journal.pone.0057770.

LaPointe DA, Goff ML, Atkinson CT. 2010. Thermal Constraints to the Sporogonic Development and Altitudinal Distribution of Avian Malaria Plasmodium relictum in Hawai'i. The Journal of Parasitology 96:318-324. DOI: 10.1645/GE-2290.1.

Levin II, Parker PG. 2012. Prevalence of Hemoproteus iwa in Galapagos Great Frigatebirds (Fregata minor) and their obligate fly ectoparasite (Olfersia spinifera). Journal of Parasitology 98:924-929. DOI: 10.1645/GE-3027.1.

Levin II, Valkiūnas G, Iezhova TA, O’Brien SL, Parker PG. 2012. Novel Haemoproteus Species (Haemosporida : Haemoproteidae) from the Swallow- Tailed Gull (Lariidae), with Remarks On the Host Range of Hippoboscid- Transmitted Avian Hemoproteids. Journal of Parasitology 98:847-854. DOI: 10.1645/GE-3007.1.

Lopes VL, Costa F V., Rodrigues RA, Braga M, Pichorim M, Moreira PA. 2020. High fidelity defines the temporal consistency of host-parasite interactions in a tropical coastal ecosystem. Scientific Reports 10:1-10. DOI: 10.1038/s41598-020-73563-6. 
602 Lutz HL, Hochachka WM, Engel JI, Bell JA, Tkach V V., Bates JM, Hackett SJ, Weckstein JD.

603 2015. Parasite prevalence corresponds to host life history in a diverse assemblage of

604 afrotropical birds and haemosporidian parasites. PLoS ONE 10:1-24. DOI:

$605 \quad$ 10.1371/journal.pone.0121254.

606 Matthews AE, Ellis VA, Hanson AA, Roberts JR, Ricklefs RE, Collins MD. 2015. Avian

607 haemosporidian prevalence and its relationship to host life histories in eastern Tennessee.

608 Journal of Ornithology 157:1-16. DOI: 10.1007/s10336-015-1298-y.

609 Medeiros MCI, Ricklefs RE, Brawn JD, Ruiz MO, Goldberg TL, Hamer GL. 2016. Overlap in

610 the seasonal infection patterns of avian malaria parasites and West Nile Virus in vectors and

611 hosts. The American Journal of Tropical Medicine and Hygiene 95:1121-1129. DOI:

$612 \quad$ 10.4269/ajtmh.16-0236.

613 Mellor PS, Boorman J, Baylis M. 2000. Culicoides Biting Midges : Their Role as Arbovirus

$614 \quad$ Vectors. Annual Review Entomology 45:307-340.

615 Møller AP. 2010. Host-parasite interactions and vectors in the barn swallow in relation to climate 616 change. Global Change Biology 16:1158-1170. DOI: 10.1111/j.1365-2486.2009.02035.x.

617 Møller AP, Erritzøe J. 1998. Host immune defence and migration in birds. Evolutionary Ecology $618 \quad 12: 945-953$.

619 Mordecai EA, Caldwell JM, Grossman MK, Lippi CA, Johnson LR, Neira M, Rohr JR, Ryan SJ, 620 Savage V, Shocket MS, Sippy R, Stewart Ibarra AM, Thomas MB, Villena O. 2019.

621 Thermal biology of mosquito-borne disease. Ecology Letters 22:1690-1708. DOI:

622 10.1111/ele.13335.

623 Nakagawa S, Johnson PCD, Schielzeth H. 2017. The coefficient of determination R2 and intra624 class correlation coefficient from generalized linear mixed-effects models revisited and 
expanded. Journal of the Royal Society Interface 14:1-11. DOI:

626 http://dx.doi.org/10.1098/rsif.2017.0213.

627 Nakagawa S, Schielzeth H. 2013. A general and simple method for obtaining R2 from 628 generalized linear mixed-effects models. Methods in Ecology and Evolution 4:133-142. DOI: $10.1111 /$ j.2041-210x.2012.00261.x.

Ortego J, Cordero PJ, Aparicio JM, Calabuig G. 2008. Consequences of chronic infections with three different avian malaria lineages on reproductive performance of Lesser Kestrels (Falco naumanni). Journal of Ornithology 149:337-343. DOI: 10.1007/s10336-008-02879.

Padilla LR, Whiteman NK, Merkel J, Huyvaert KP, Parker G, Padilla LR, Whiteman NK, Merkel J, Huyvaert KP, Parker PG. 2006. Health Assesment of seabirds on Isla Genovesa, Galapagos Islands. Ornithological Monographs:86-97.

640

641

642 2019. Migratory birds as vehicles for parasite dispersal? Infection by avian haemosporidians 643 over the year and throughout the range of a long - distance migrant. Journal of 644 Biogeography 46:83-96. DOI: 10.1111/jbi.13453.

645 R Core Team. 2016. R: A language and environment for statistical computing.

646 Ribeiro SF, Sebaio F, Branquinho FCS, Marini MÂ, Vago AR, Braga ÉM. 2005. Avian malaria 647 in Brazilian passerine birds: Parasitism detected by nested PCR using DNA from stained

Patz J a., Graczyk TK, Geller N, Vittor AY. 2000. Effects of environmental change on emerging parasitic diseases. International Journal for Parasitology 30:1395-1405. DOI:

10.1016/S0020-7519(00)00141-7.

Pulgarín-R PC, Gómez C, Bayly NJ, Bensch S, Fitzgerald AM, Starkloff N, Kirchman JJ, González-Prieto AM, Hobson KA, Ungvari-Martin J, Skeen H, Castaño MI, Cadena CD. 
648

649 Richner H, Christe P, Oppliger A. 1995. Paternal investment affects prevalence of malaria.

$650 \quad$ Proceedings of the National Academy of Sciences of the United States of America 92:1192-

651 4. DOI: $10.1073 /$ pnas.92.4.1192.

652 Ricklefs RE, Fallon SM. 2002. Diversification and host switching in avian malaria parasites.

653 Proceedings of the Royal Society London B 269:885-892. DOI: 10.1098/rspb.2001.1940.

654 Ricklefs RE, Medeiros M, Ellis VA, Svensson-Coelho M, Blake JG, Loiselle BA, Soares L,

655 Fecchio A, Outlaw D, Marra PP, Latta SC, Valkiūnas G, Hellgren O, Bensch S. 2017.

656 Avian migration and the distribution of malaria parasites in New World passerine birds.

657 Journal of Biogeography 44:1113-1123. DOI: 10.1111/jbi.12928.

658 Ricklefs RE, Outlaw DC, Svensson-Coelho M, Medeiros MCI, Ellis VA, Latta S. 2014. Species

659 formation by host shifting in avian malaria parasites. Proceedings of the National Academy

660 of Sciences 111:14816-14821. DOI: 10.1073/pnas.1416356111.

661 Ricklefs RE, Soares L, Ellis VA, Latta SC. 2016. Haemosporidian parasites and avian host

662 population abundance in the Lesser Antilles. Journal of Biogeography 43:1277-1286. DOI:

$663 \quad 10.1111 / \mathrm{jbi} .12730$.

664 Ricklefs RE, Swanson BL, Fallon SM, Martinez-Abrain A, Scheuerlein A, Gray J, Latta S. 2005.

665 Community relationships of avian malaria parasites in southern Missouri. Ecological

666 Monographs 75:543-559. DOI: 10.1890/04-1820.

667 van Riper III C, van Riper SG, Goff ML, Laird M. 1986. The epizootiology and ecological

668 significance of malaria in Hawaiian land birds. Ecological Monographs 56:327-344.

669 Rodrigues RA, Massara RL, Bailey LL, Pichorim M, Moreira PA, Braga ÉM. 2020. Using a

670 multistate occupancy approach to determine molecular diagnostic accuracy and factors 
671 affecting avian haemosporidian infections. Scientific Reports 10:1-10. DOI:

$672 \quad 10.1038 / \mathrm{s} 41598-020-65523-x$.

673 Santiago-Alarcon D, Bloch R, Rolshausen G, Schaefer HM, Segelbacher G. 2011. Prevalence, 674 diversity, and interaction patterns of avian haemosporidians in a four year study of 675 blackcaps in a migratory divide Prevalence, diversity, and interaction patterns of avian 676 haemosporidians in a four-year study of blackcaps in a migrator. Parasitology 138:824677 835. DOI: $10.1017 / \mathrm{S} 0031182011000515$.

678 Santiago-Alarcon D, Palinauskas V, Schaefer HM. 2012. Diptera vectors of avian 679 Haemosporidian parasites: Untangling parasite life cycles and their taxonomy. Biological 680 Reviews 87:928-964. DOI: 10.1111/j.1469-185X.2012.00234.x.

681 Scott ME. 1988. The impact of infection and disease on animal populations: Implications for 682 conservation biology. Conservation Biology 2:40-56. DOI: 10.1111/j.1523$683 \quad$ 1739.1988.tb00334.x.

684 Sebaio F, Braga ÉM, Branquinho F, Manica LT, Marini MÂ. 2010. Blood parasites in Brazilian 685 Atlantic Forest birds: effects of fragment size and habitat dependency. Bird Conservation 686 International 20:432-439. DOI: 10.1017/S0959270910000110.

687 Sehgal RNM, Buermann W, Harrigan RJ, Bonneaud C, Loiseau C, Chasar A, Sepil I, Valkiūnas 688 G, Iezhova T, Saatchi S, Smith TB. 2011. Spatially explicit predictions of blood parasites in 689 a widely distributed African rainforest bird. Proceedings of the Royal Society B: Biological 690 Sciences 278:1025-1033. DOI: 10.1098/rspb.2010.1720.

691 Slowinski SP, Fudickar AM, Hughes AM, Mettler RD, Gorbatenko O V, Spellman GM, 692 Ketterson ED, Atwell JW. 2018. Sedentary songbirds maintain higher prevalence of 693 haemosporidian parasite infections than migratory conspecifics during seasonal sympatry. 
695 Soares L, Latta SC, Ricklefs RE. 2019. Neotropical migratory and resident birds occurring in 696 sympatry during winter have distinct haemosporidian parasite assemblages. Journal of 697 Biogeography 47:1-12. DOI: 10.1111/jbi.13760.

698 Soares L, Young EI, Ricklefs RE. 2020. Haemosporidian parasites of resident and wintering 699 migratory birds in The Bahamas. Parasitology Research 119:1563-1572. DOI:

700 10.1007/s00436-020-06646-y.

701 Somenzari M, Amaral PP, Cueto VR, Guaraldo AC, Jahn AE, Lima DM, Lima PC, Lugarini C, 702 Machado CG, Martinez J, Nascimento JLX, Pacheco JF, Paludo D, Prestes NP, Serafini PP, 703 Silveira LF, Sousa AEBA, Sousa NA, Souza MA, Telino-Júnior WR, Whitney BM. 2018. 704 An overview of migratory birds in Brazil. DOI: 10.11606/1807-0205/2018.58.03.

705

706

707

708

709

710

711

712

713

714

715

716

Spencer KA, Buchanan KL, Leitner S, Goldsmith AR, Catchpole CK. 2005. Parasites affect song complexity and neural development in a songbird. Proceedings of the Royal Society B: Biological Sciences 272:2037-2043. DOI: 10.1098/rspb.2005.3188.

Svensson-Coelho M, Blake JGJG, Loiselle B a, Penrose a. SAS, Parker PG, Ricklefs RE. 2013. Diversity, prevalence, and host specificity of avian Plasmodium and Haemoproteus in a western Amazon assemblage. Ornithological Monographs 76:1-47. DOI: 10.1525/om.2013.76.1.1.

Valkiūnas G. 2005. Avian malaria parasites and other Haemosporidia. Boca Raton, Florida: CRC Press.

Waldenström J, Bensch S, Kiboi S, Hasselquist D, Ottosson U. 2002. Cross-species infection of blood parasites between resident and migratory songbirds in Africa. Molecular Ecology 11:1545-1554. DOI: 10.1046/j.1365-294X.2002.01523.x. 
717 Wilman H, Belmaker J, Simpson J, de la Rosa C, Rivadeneira MM, Jetz W. 2014. EltonTraits

718 1.0: Species-level foraging attributes of the world's birds and mammals. Ecology 95:2027-

719 2027. DOI: $10.1890 / 13-1917.1$.

720 Wood MJ, Cosgrove CL, Wilkin TA, Knowles SCL, Day KP, Sheldon BC. 2007. Within-

721 population variation in prevalence and lineage distribution of avian malaria in blue tits,

722 Cyanistes caeruleus. Molecular ecology 16:3263-3273. DOI: 10.1111/j.1365-

$723 \quad 294 X .2007 .03362 . x$.

724 Work TM, Rameyer RA. 1996. Haemoproteus iwa n . sp . in Great Frigatebirds (Fregata minor

725 [Gmelin]) from Hawaii: Parasite morphology and prevalence. The Journal of Parasitology

$726 \quad 82: 489-491$.

727 Zamora-Vilchis I, Williams SE, Johnson CN. 2012. Environmental temperature affects

728 prevalence of blood parasites of birds on an elevation gradient: Implications for disease in a 729 warming climate. PLoS ONE 7:1-8. DOI: 10.1371/journal.pone.0039208. 


\section{Table $\mathbf{1}$ (on next page)}

Distribution of Plasmodium lineages across bird species captured in Barreira do Inferno Rocket Launch Center of the Brazilian Air Force, Parnamirim, State of Rio Grande do Norte, Brazil.

The number of individuals captured for each species is denoted in parentheses. 
1 Table 1: Distribution of Plasmodium lineages across bird species captured in Barreira do Inferno Rocket Launch Center of the

2 Brazilian Air Force, Parnamirim, State of Rio Grande do Norte, Brazil.

3 The number of individuals captured for each species is denoted in parentheses.

4

Plasmodium lineages

Bird species

BAFLA03 BAFLA04 CALON01 CPCT57 DENPET03 FOGRI01 FOMEL04

H012

HYAMA01

Cantorchilus longirostris (25)

2

Coereba flaveola (114)

Cyanocorax cyanopogon (2)

Cyclarhis gujanensis (14)

Elaenia chilensis (244)

1

Elaenia spectabilis (9)

Formicivora grisea (10)

Formicivora melanogaster (9)

Herpsilochmus pectoralis (24)

Herpsilochmus sellowi (27)

Hylophilus amaurocephalus (29)

Leptotila verreauxi (9) 
Polioptila plúmbea (15)

Tachyphonus rufus (108)

1

Turdus amaurochalinus (156) 1

Turdus flavipes (11)

1

Turdus leucomelas (98)

Plasmodium lineages

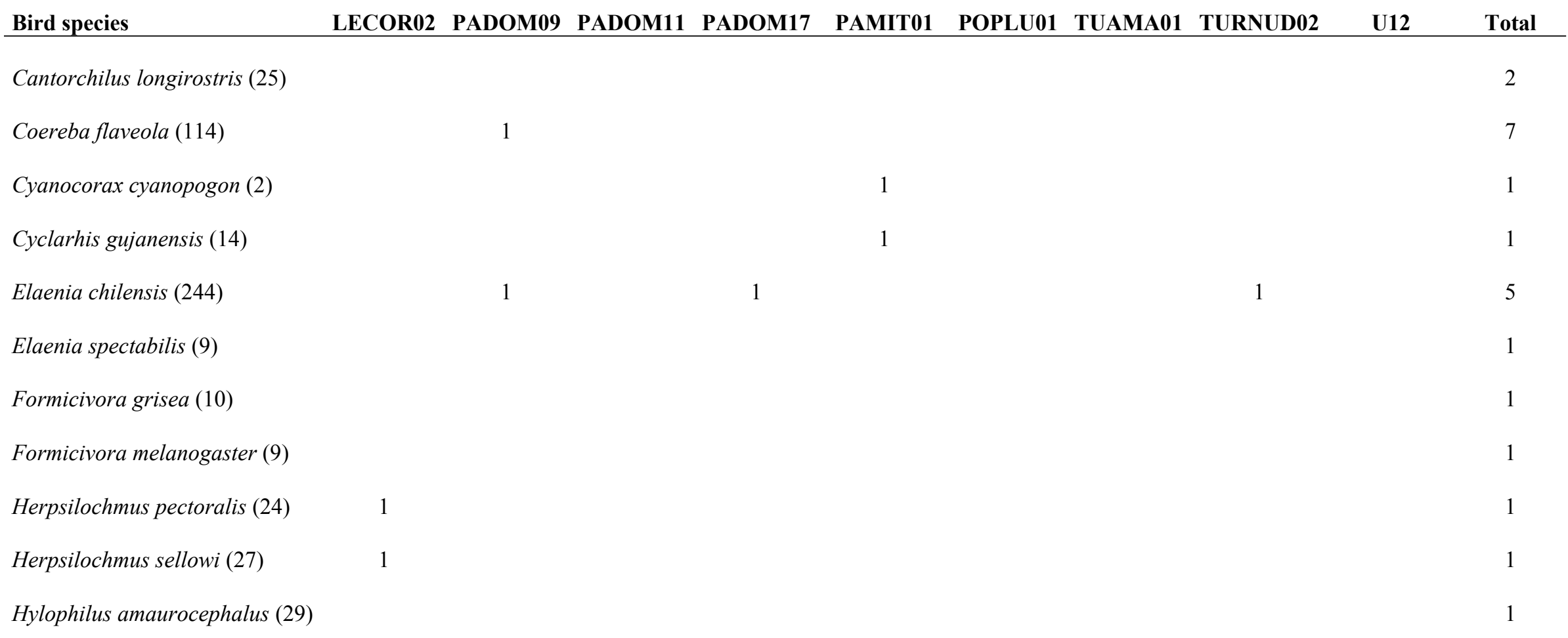


Leptotila verreauxi (9)

Piaya cayana (8)

Polioptila plúmbea (15)

1

1

Tachyphonus rufus (108)

1

Turdus amaurochalinus (156)

1

Turdus flavipes (11)

1

1

3

2

Turdus leucomelas (98)

1

1 


\section{Table 2 (on next page)}

Distribution of Haemoproteus lineages across bird species captured in Barreira do Inferno Rocket Launch Center of the Brazilian Air Force, Parnamirim, State of Rio Grande do Norte, Brazil.

The number of individuals captured for each species is denoted in parentheses. SocH3, SocH4 and COTALO1 are Haemoproteus (Haemoproteus) lineages. ELALB01, NYMAC01, PAPOL03, TARUF02, UN203 and VIREO02 are Haemoproteus (Parahaemoproteus) lineages. 
1 Table 2: Distribution of Haemoproteus lineages across bird species captured in Barreira do Inferno Rocket Launch Center of 2 the Brazilian Air Force, Parnamirim, State of Rio Grande do Norte, Brazil.

3 The number of individuals captured for each species is denoted in parentheses. SocH3, SocH4 and COTAL01 are Haemoproteus

4 (Haemoproteus) lineages. ELALB01, NYMAC01, PAPOL03, TARUF02, UN203 and VIREO02 are Haemoproteus 5 (Parahaemoproteus) lineages. 
Haemoproteus lineages

\begin{tabular}{|c|c|c|c|c|c|c|c|c|c|c|c|}
\hline & & & & & & & & & & & \\
\hline Bird species & Família & $\begin{array}{c}\text { COTALO } \\
1\end{array}$ & $\begin{array}{c}\text { ELALB0 } \\
1\end{array}$ & $\begin{array}{c}\text { NYMAC0 } \\
1 \\
\end{array}$ & $\begin{array}{c}\text { PAPOLO } \\
\mathbf{3} \\
\end{array}$ & $\begin{array}{c}\text { SocH } \\
3\end{array}$ & $\begin{array}{c}\text { SocH } \\
4\end{array}$ & $\begin{array}{c}\text { TARUF0 } \\
2 \\
\end{array}$ & UN203 & $\begin{array}{l}\text { VIREOO } \\
2 \\
\end{array}$ & $\begin{array}{c}\text { Tota } \\
1\end{array}$ \\
\hline Coereba flaveola (114) & Thraupidae & & & & & & & 1 & & & 1 \\
\hline Columbina passerina (21) & Columbidae & & & & & 4 & 1 & & & & 5 \\
\hline Columbina talpacoti (14) & Columbidae & 4 & & & & & & & & & 4 \\
\hline Coryphospingus pileatus (5) & Thraupidae & & & & & & & 1 & & & 1 \\
\hline Cyclarhis gujanensis (14) & Vireonidae & & & & & & & 1 & 5 & & 6 \\
\hline Elaenia chilensis (244) & Tyrannidae & & 1 & & & & & & 1 & & 2 \\
\hline Formicivora grisea (10) & $\begin{array}{c}\text { Thamnophilida } \\
\text { e }\end{array}$ & & & & & & & 1 & & & 1 \\
\hline Myiarchus tyrannulus (4) & Tyrannidae & & 1 & & & & & & & & 1 \\
\hline Neopelma pallescens (27) & Pipridae & & & & & & & 1 & & & 1 \\
\hline Nystalus maculatus (10) & Bucconidae & & & 3 & & & & & & & 3 \\
\hline $\begin{array}{l}\text { Pachyramphus polychopterus } \\
\text { (7) }\end{array}$ & Tityridae & & & & 2 & & & & & & 2 \\
\hline Tachyphonus rufus (108) & Thraupidae & & & & & & & 37 & & & 37 \\
\hline Tangara cayana (67) & Thraupidae & & & & & & & 1 & & & 1 \\
\hline Turdus flavipes (11) & Turdidae & & & & & & & 1 & & & 1 \\
\hline Vireo chivi (10) & Vireonidae & & & & & & & & & 1 & 1 \\
\hline
\end{tabular}




\section{Table 3(on next page)}

The parameters of the minimal models (binomial GLMMs) explaining the probability of infection by Plasmodium sp. and Parahaemoproteus sp.

Both models have the same random structure (see Supplementary Tables 1 - 3). 
1 Table 3: The parameters of the minimal models (binomial GLMMs) explaining the 2 probability of infection by Plasmodium sp. and Parahaemoproteus sp.

3 Both models have the same random structure (see Supplementary Tables 1 - 3).

\begin{tabular}{|c|c|c|c|c|c|c|c|c|}
\hline Parasite Genus & $\begin{array}{c}\text { Main } \\
\text { Effects }\end{array}$ & Estimate & $\begin{array}{l}\text { Std. } \\
\text { Error }\end{array}$ & $\begin{array}{l}\text { Odds } \\
\text { ratio }\end{array}$ & $\begin{array}{c}\mathrm{Z} \\
\text { value }\end{array}$ & P value & $\mathbf{R} \mathbf{2}_{\mathrm{m}}$ & $\mathbf{R} \mathbf{2}_{\mathrm{c}}$ \\
\hline \multirow[t]{2}{*}{ Plasmodium } & Intercept & -2.85 & 0.32 & 0.05 & -8.69 & $2 \mathrm{e}-16^{*}$ & 0.08 & 0.24 \\
\hline & Temperature & 0.59 & 0.21 & 1.80 & 2.73 & $0.0060 *$ & & \\
\hline \multirow[t]{2}{*}{ Parahaemoproteus } & Intercept & -0.70 & 0.19 & 0.49 & -3.60 & $0.0003 *$ & 0.43 & 0.43 \\
\hline & Migratory & -3.37 & 0.54 & 0.03 & -6.42 & $4.32 \mathrm{e}-10^{*}$ & & \\
\hline
\end{tabular}

4 
Figure 1

Map of the study site sampled for a bird community infected by Plasmodium and Haemoproteus, Barreira do Inferno Rocket Launch Center of the Brazilian Air Force, Parnamirim, State of Rio Grande do Norte, Brazil. We sampled 36 to 49 points per m
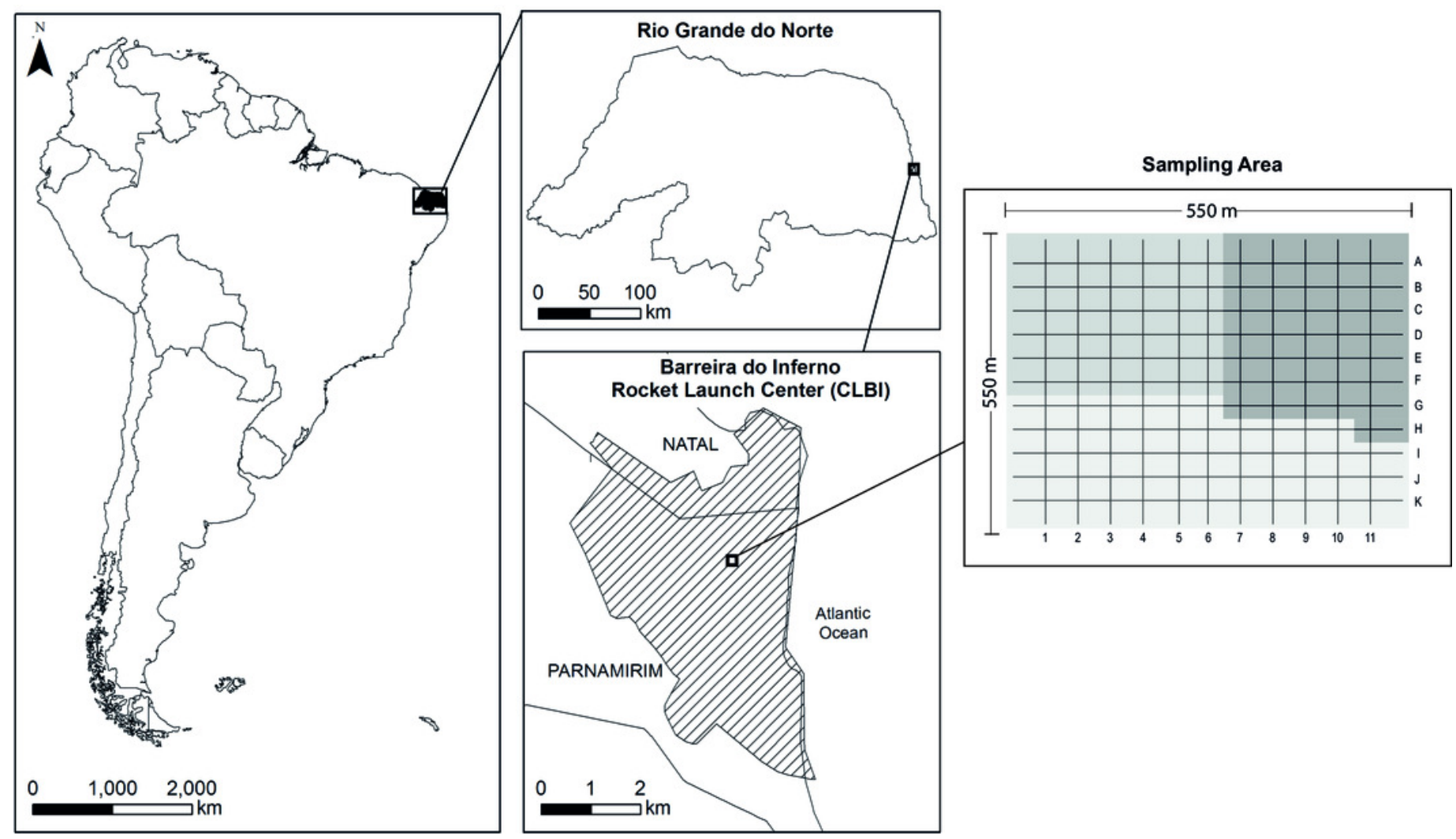